\title{
MODAL SOSIAL, STRATEGI KOPING EKONOMI, DAN KESEJAHTERAAN OBJEKTIF KELUARGA DENGAN PEREMPUAN SEBAGAI KEPALA KELUARGA
}

\author{
Hurriyyatun Kabbaro $\left.^{1 *}\right)$, Hartoyo ${ }^{1}$, Lilik Noor Yuliati ${ }^{1}$ \\ ${ }^{1}$ Departemen IImu Keluarga dan Konsumen, Fakultas Ekologi Manusia, Institut Pertanian Bogor, \\ Bogor 16680, Indonesia
}

*) E-mail: hurriyyatun.kabbaro@gmail.com

\begin{abstract}
Abstrak
Jumlah perempuan sebagai kepala keluarga cenderung meningkat di Indonesia. Struktur keluarga yang baru dengan ibu berfungsi sekaligus sebagai kepala keluarga menyebabkan berbagai penyesuaian, khususnya untuk mempertahankan keluarga tetap sejahtera. Penelitian ini bertujuan untuk menganalisis modal sosial, strategi koping ekonomi, dan kesejahteraan objektif keluarga dengan perempuan sebagai kepala keluarga (Pekka). Penelitian ini bertempat di Kabupaten Bogor dengan desain studi cross-sectional. Penelitian ini melibatkan 53 perempuan kepala keluarga yang bercerai kurang dari dua tahun. Pengambilan data dilakukan melalui wawancara menggunakan kuesioner dengan teknik snowball. Hasil penelitian menunjukkan hampir 75 persen keluarga keluarga dengan perempuan sebagai kepala keluarga berpenghasilan di atas garis kemiskinan. Analisis regresi logistik menunjukkan bahwa usia ibu berpeluang memiliki pengaruh terhadap kesejahteraan objektif secara signifikan positif pada keluarga dengan perempuan sebagai kepala keluarga. Kesejahteraan objektif keluarga dengan perempuan sebagai kepala keluarga dipengaruhi oleh kepercayaan dan jaringan sosial. Hasil penelitian memperkirakan penurunan strategi pengurangan pengeluaran yang dilakukan keluarga dengan perempuan sebagai kepala keluarga berpeluang lebih besar untuk mengidentifikasikan keluarga menjadi lebih sejahtera secara objektif.
\end{abstract}

Kata kunci: kesejahteraan objektif, modal sosial, perempuan sebagai kepala keluarga (Pekka), strategi koping ekonomi

\section{Social Capital, Economic Coping Strategy, and Objective Well-Being of Female- Headed Families}

\begin{abstract}
Number of female-headed families tended to increase in Indonesia. The new family structures with maternal functions simultaneously as head of the family led to various adjustments, especially to maintain the family welfare. This research was aimed to analyze social capital, economic coping strategy, and objective well-being of female-headed families. This research held in Bogor District and used cross sectional design. This research involved 53 female-headed families who have been became single-parent since last two years. The families were chosen by snowball sampling and the data was obtained by interview using questionnaire. The result showed that more than half of female-headed families had income over the poverty line. Analysis of logistic regression discovered female-headed's age had significant chance to have positive influence on family objective well-being. Family objective well-being was influenced by social capital variable particularly in dimension of trust and social network. This research estimated that decreasing of cutting back expenses strategy will give higher chance to identify family to be more prosperous objectively.
\end{abstract}

Keywords: economic coping strategy, female-headed families, objective well-being, social capital

\section{PENDAHULUAN}

Kemiskinan merupakan salah satu masalah kompleks dan berkepanjangan yang dihadapi oleh banyak negara salah satunya Indonesia. Berdasarkan data Badan Pusat Statistik tahun 2013 , terdapat 28,59 juta orang $(11,66 \%)$ penduduk miskin di Indonesia hingga bulan September 2012. Persentase ini mengalami penurunan sebesar 0,54 juta orang
$(0,30 \%)$ dibandingkan dengan penduduk miskin pada bulan Maret 2012, yaitu sebesar 29,13 juta orang $(11,96 \%)$. Sementara itu, berdasarkan data Bank Dunia (2013) bahwa hampir 50 persen penduduk Indonesia masih hidup dengan penghasilan di bawah US\$2 per hari.

Kemiskinan merupakan gambaran dari rendahnya kesejahteraan (Wagle, 2008). 
Upaya pencapaian kesejahteraan tidak terlepas dari optimalisasi fungsi dalam sistem keluarga. Keluarga dengan perempuan sebagai kepala keluarga (Pekka) merupakan suatu keadaan keluarga dengan ayah meninggal dunia (cerai mati) atau berpisah dengan ibu (cerai hidup) sehingga menyebabkan perempuan yang selama ini berstatus istri menjadi kepala keluarga. Rumah tangga yang dikepalai perempuan umumnya miskin dan merupakan kelompok termiskin dalam strata sosial ekonomi di Indonesia (Forum Pekka, 2013). Keluarga Pekka memiliki tingkat produktivitas kerja yang lebih rendah dibandingkan keluarga dengan laki-laki sebagai kepala keluarga (Horrell \& Krishnan, 2006). Kondisi ini diiringi fakta jumlah perempuan kepala keluarga di Indonesia mengalami peningkatan dengan rata-rata 0,1 persen per tahun (Forum Pekka, 2013).

Sejumlah penelitian telah mengkaji kehidupan keluarga Pekka. Kajian Eboiyehi (2013) membahas mengenai strategi bertahan hidup perempuan kepala keluarga usia tua berdasarkan pekerjaan yang bisa dilakukan di perkotaan. Karakteristik Pekka dengan ciri memiliki tingkat literasi yang rendah, pencapaian pendidikan yang rendah, memegang aset yang rendah, tingkat kurang gizi yang tinggi, dan resiko kematian yang tinggi dikaji oleh Joshi (2004). Grotraert (1999) mengkaji perbandingan tingkat partisipasi perempuan sebagai kepala keluarga dan lakilaki sebagai kepala keluarga dalam kelompok sosial. Penelitian sebelumnya mengkaji strategi bertahan hidup sebagai koping, karakteristik, dan modal sosial perempuan sebagai kepala keluarga secara terpisah. Belum ditemukan kajian komprehensif yang membahas strategi koping ekonomi dan modal sosial keluarga Pekka, khususnya bagi keluarga Pekka yang baru bercerai dan masih memiliki anak sekolah. Pada masa ini, perempuan kepala keluarga akan dihadapkan oleh dua tantangan, yakni bagaimana menjalankan fungsi domestik (pengasuhan dan rumah tangga) dan fungsi instrumental (pencarian nafkah).

Strategi koping merupakan upaya seseorang untuk menguasai, mengurangi, dan menoleransi tuntutan atau masalah yang dihadapi (Hastuti \& Milyawati, 2009). Puspitawati (2012) membagi dua jenis strategi koping ekonomi keluarga, yaitu penambahan pendapatan (generating additional income) dan pengurangan pengeluaran (cutting back expenses). Strategi koping yang dilakukan keluarga tergantung pada tingkat kemiskinan keluarga (Puspitawati, 1998 diacu dalam Johan, Muflikhati, \& Mukhti, 2013). Hasil penelitian menunjukkan bahwa semakin sejahtera keluarga akan semakin sedikit melakukan strategi koping (Rosidah, Hartoyo, \& Muflikhati, 2012).

Strategi koping dapat didukung dengan sumber daya yang dimiliki keluarga, salah satunya adalah modal sosial. Modal sosial dapat membantu rumah tangga dalam upaya strategi koping terhadap resiko fluktuasi pendapatan (Grootaert, 1999). Keluarga yang mengikuti perkumpulan dan organisasi kooperatif untuk bertahan dan meningkatkan kesejahteraan (Chamwali, 2000). Sejalan dengan penelitian Sunarti dan Fitriani (2010) bahwa semakin tinggi jumlah asosiasi lokal yang diikuti, tingkat keaktifan, dan manfaat yang dirasakan keluarga maka semakin tinggi pendapatan keluarga.

Belum banyak penelitian mengenai strategi koping dan modal sosial pada keluarga Pekka. Kesejahteraan objektif diangkat dalam penelitian ini dengan alasan peran ganda yang diterima oleh perempuan sebagai kepala keluarga terdorong dari tekanan ekonomi yang tinggi. Hal ini menyebabkan perempuan sebagai kepala keluarga harus menjalankan fungsi keluarga untuk mencari nafkah sebagai peran utama. Berdasarkan pemaparan di atas, kajian mengenai strategi koping ekonomi dan modal sosial pada keluarga Pekka penting dilakukan mengingat angka perempuan keluarga semakin meningkat. Penelitian ini bertujuan menganalisis strategi koping ekonomi, modal sosial, dan kesejahteraan objektif keluarga Pekka.

\section{METODE}

Penelitian ini merupakan studi dengan desain cross sectional dan dilaksanakan selama bulan Juni 2014. Lokasi penelitian adalah Kabupaten Bogor Provinsi Jawa Barat, khususnya di Kecamatan Dramaga, Ciampea, dan Cibungbulang. Lokasi penelitian dipilih secara purposif dengan karakteristik perdesaan yang berdekatan dengan perkotaan.

Responden dalam penelitian ini adalah 53 perempuan kepala keluarga dalam periode 2 tahun pasca perceraian dan memiliki anak sekolah yang diambil secara snowball. Jumlah responden merupakan pertimbangan dari jumlah kebutuhan minimum statistik. Berdasarkan Farrington, Ramasut, dan Walker (2002) strategi koping hanya dilakukan keluarga ketika menghadapi kritis pada jangka pendek. Periode 2 tahun digunakan sebagai pertimbangan responden dapat mengingat lebih 
baik terhadap strategi koping yang digunakan mulai dari awal krisis.

Pengambilan data dilakukan dengan wawancara menggunakan kuesioner. Data primer terdiri atas karakteristik keluarga, modal sosial, dan strategi koping keluarga. Kuesioner modal sosial diacu dan dimodifikasi dari Hastuti, Alfiasari, dan Sarwoprasodjo (2009) dengan nilai Cronbach's alpha sebesar 0,730 (kepercayaan), 0,723 (jaringan sosial), dan 0,847 (norma sosial). Pengukuran kepercayaan meliputi tingkat kepercayaan diri dalam mengelola kehidupan di dalam keluarga dan masyarakat. Dimensi ini menggunakan empat penilaian untuk empat tingkatan, yaitu skor 1 untuk pilihan jawaban "tidak ada", skor 2 untuk pilihan jawaban "ada dan sedikit", skor 3 untuk pilihan jawaban "ada dan cukup", skor 4 untuk pilihan jawaban "ada dan banyak". Jaringan sosial dibagi menjadi dua, yaitu pertama, jumlah, heterogenitas, dan manfaat yang dirasakan keluarga terhadap jaringan sosial yang dimiliki. Kedua, keterlibatan keluarga dalam organisasi atau kelompok sosial yang diikuti. Pengukuran jumlah dan manfaat jaringan sosial menggunakan empat penilaian untuk empat tingkatan, yaitu skor 1 untuk pilihan jawaban "tidak ada", skor 2 untuk pilihan jawaban "ada dan sedikit", skor 3 untuk pilihan jawaban "ada dan cukup", skor 4 untuk pilihan jawaban "ada dan banyak".

Pengukuran keterlibatan keluarga menggunakan empat penilaian untuk empat tingkatan, yaitu skor 1 untuk pilihan jawaban "tidak aktif", skor 2 untuk pilihan jawaban "kurang aktif", skor 3 untuk pilihan jawaban "aktif", skor 4 untuk pilihan jawaban "sangat aktif". Norma merupakan kontrol sosial dan sumber konsensus dari harapan dan komitmen, termasuk sanksi, kebiasaan, adat istiadat, dan struktur sosial. Pengukuran norma sosial meliputi nilai kejujuran, nilai menjaga komitmen dan tanggung jawab, nilai tolong menolong, dan nilai saling menghargai. Dimensi ini menggunakan empat penilaian untuk empat tingkatan, yaitu skor 1 untuk pilihan jawaban "tidak pernah", skor 2 untuk pilihan jawaban "kadang-kadang", skor 3 untuk pilihan jawaban "sering", dan skor 4 untuk pilihan jawaban "selalu".

Kuesioner strategi koping diacu dan dimodifikasi dari Puspitawati (2012) dengan nilai Cronbach's alpha sebesar 0,820. Instrumen tersebut memiliki dua dimensi pengukuran pada variabel strategi koping, yaitu penambahan pendapatan (generating additional income) dan pengurangan pengeluaran (cutting back expenses). Pengukuran strategi koping ekonomi menggunakan empat penilaian untuk empat tingkatan, yaitu tidak pernah (skor 1), kadangkadang (skor 2), sering (skor 3), dan selalu (skor 4).

Kesejahteraan objektif keluarga dapat diukur dengan menggunakan garis kemiskinan BPS dan Bank Dunia. Indikator BPS mengategorikan keluarga ke dalam keluarga miskin dan tidak miskin. Keluarga miskin merupakan keluarga yang memiliki rata-rata pendapatan per kapita per bulan sama atau di bawah garis kemiskinan. Garis kemiskinan yang digunakan adalah garis kemiskinan Kabupaten Bogor tahun 2011 sebesar Rp235.682 per kapita per bulan (BPS, 2011). Bank Dunia mengukur kesejahteraan menggunakan garis kemiskinan Bank Dunia, yaitu penghasilan sebesar US $\$ 1,25$ per hari dan US\$2 per hari. Acuan kurs menggunakan Purchasing Power Parity (PPP) atau nilai tukar daya beli, yakni sebesar Rp7.800,00 untuk garis kemiskinan US $\$ 1,25$ dan Rp12.480,00 untuk garis kemiskinan US\$2. Data strategi koping dan modal sosial yang diperoleh dijumlahkan dan dikonversi dalam bentuk indeks untuk memperoleh nilai minimum 0 dan nilai maksimum 100. Kemudian skor indeks yang dicapai tersebut dimasukkan dikategorikan berdasarkan interval kelas. Skor dikelompokkan menjadi tiga kategori, yaitu kategori rendah $(0,00-33,33)$, sedang $(33,34-$ $66,67)$, dan tinggi $(66,68-100,00)$.

Data yang telah dikategorikan dan diubah dalam bentuk indeks diolah dengan menggunakan program Microsoft Excel dan SPSS for windows. Analisis deskriptif digunakan untuk memperoleh rata-rata, standar deviasi, nilai minimum dan maksimum, tabulasi silang, dan persentase. Uji regeresi logistik digunakan untuk mengukur pengaruh karakteristik keluarga, strategi koping ekonomi, dan modal sosial terhadap kesejahteraan objektif keluarga.

\section{HASIL}

\section{Karakteristik Keluarga}

Hasil analisis deskriptif karakteristik keluarga menunjukkan rata-rata ibu berusia 42,1 tahun. Hal ini menunjukkan bahwa ratarata ibu berada pada usia dewasa madya. Rata-rata ibu menempuh pendidikan hingga 7,8 tahun atau setara dengan tamat Sekolah Dasar (SD). Rata-rata pendidikan ibu telah mencapai pendidikan Sekolah Menengah Pertama (SMP) atau sederajat meskipun tidak menamatkannya. 
Rata-rata pendapatan per kapita keluarga mencapai Rp417.410 per bulan. Angka ini berada di atas Garis Kemiskinan Kabupaten Bogor 2011 yaitu sebesar Rp235.862 sehingga rata-rata pendapatan per kapita keluarga termasuk ke dalam kategori tidak miskin. Pendapatan per kapita keluarga yang paling kecil yaitu Rp137.500 per bulan dan tergolong miskin. Pendapatan per kapita keluarga tertinggi mencapai Rp1.175.000. Rata-rata pengeluaran keluarga untuk pangan per bulan sebesar Rp1.410.000. Sementara itu, rata-rata pengeluaran nonpangan keluarga sebesar Rp443.000. Pengeluaran pangan per bulan keluarga lebih besar dibandingkan dengan pengeluaran nonpangan keluarga.

Rata-rata besar keluarga responden termasuk ke dalam keluarga kecil ( $<4$ orang). Berdasarkan status cerai, lebih dari tiga per empat ibu $(81,1 \%)$ berstatus cerai mati (suami meninggal dunia). Sedangkan ibu berstatus cerai hidup sebanyak 10 orang $(18,9 \%)$. Jumlah tanggungan keluarga maksimum mencapai 5 orang $(3,8 \%)$, sedangkan jumlah tanggungan keluarga minimum sebanyak 1 orang $(26,4 \%)$. Hasil penelitian menunjukkan bahwa lebih dari sepertiga keluarga responden $(35,8 \%)$ memiliki jumlah tanggungan sebanyak 2 orang. Ibu dengan pendidikan terakhir sekolah dasar bekerja sebagai buruh dan wiraswasta mencapai 40 persen. Separuh ibu yang telah menempuh wajib belajar 9 tahun atau setara SMP/sederajat $(50,0 \%)$ bekerja sebagai wiraswasta. Tiga dari lima ibu yang tamat SMA/sederajat bekerja sebagai wiraswasta. Ibu yang memiliki tingkat pendidikan tamat perguruan tinggi memiliki pekerjaan sebagai PNS $(33,3 \%)$ dan karyawan swasta $(66,6 \%)$. Secara keseluruhan, hasil penelitian menunjukkan hampir separuh ibu $(41,5 \%)$ bekerja sebagai wiraswasta

\section{Modal Sosial}

Modal sosial diukur melalui dimensi kepercayaan, jaringan sosial, dan norma sosial. Hasil penelitian menunjukkan bahwa hampir seluruh keluarga responden memiliki kepercayaan $(86,8 \%)$ yang tinggi. Lebih dari separuh keluarga responden $(56,6 \%)$ memiliki total skor variabel jaringan sosial dengan kategori tinggi. Hampir seluruh keluarga $(90,6 \%)$ memiliki total skor dengan kategori tinggi pada variabel norma sosial (Tabel 1). Secara agregat, lebih dari separuh keluarga $(52,8 \%)$ memiliki modal sosial dengan kategori tinggi. Rata-rata indeks total skor variabel modal sosial sebesar 66,7.
Tabel 1 Sebaran kategori modal sosial keluarga berdasarkan indeks total

\begin{tabular}{lcccc}
\hline \multirow{2}{*}{ Modal Sosial } & Rendah & Sedang & Tinggi & Total \\
\cline { 2 - 5 } & \multicolumn{1}{c}{$\%$} & \multicolumn{1}{c}{$\%$} & \multicolumn{1}{c}{$\%$} & \multicolumn{1}{c}{$\%$} \\
\hline Kepercayaan & 0,0 & 13,2 & 86,8 & 100,0 \\
Jaringan & 1,9 & 41,5 & 56,6 & 100,0 \\
sosial & 0,0 & 9,4 & 90,6 & 100,0 \\
Norma sosial & Keterangan: \%=Persentase & & &
\end{tabular}

\section{Strategi Koping Ekonomi}

Strategi koping ekonomi diukur melalui dua dimensi, yaitu pengurangan pengeluaran dan penambahan pendapatan. Sebaran kategori strategi koping ibu berdasarkan indeks total dapat dilihat pada Tabel 2. Hasil penelitian menunjukkan bahwa lebih dari tiga perempat keluarga responden $(79,2 \%)$ melakukan strategi pengurangan pengeluaran pada kategori sedang. Terdapat 13,20 persen keluarga responden melakukan strategi pengurangan pengeluaran pada kategori tinggi. Kurang dari sepertiga keluarga responden $(30,20 \%)$ melakukan strategi peningkatan pendapatan pada kategori rendah. Lebih dari separuh keluarga responden $(66,00 \%)$ melakukan strategi pengurangan pengeluaran pada kategori sedang. Terdapat dua keluarga responden yang memiliki indeks dengan kategori tinggi pada dimensi peningkatan pendapatan.

Secara agregat, hampir seluruh keluarga responden $(94,30 \%)$ melakukan strategi koping ekonomi pada kategori sedang. Terdapat 3,80 persen keluarga responden yang melakukan strategi koping ekonomi pada kategori rendah dan 1,90 persen keluarga responden yang melakukan strategi koping ekonomi pada kategori tinggi. Rata-rata indeks total variabel strategi koping ekonomi adalah sebesar 49,50 $(\mathrm{sd}=9,64)$. Strategi pengurangan pengeluaran (rata-rata $=51,79$ ) lebih sering dilakukan dibandingkan strategi peningkatan pendapatan (rata-rata $=41,71)$. Sebaran kategori strategi koping keluarga responden berdasarkan indeks total disajikan pada Tabel 2.

Tabel 2 Sebaran kategori strategi koping keluarga responden berdasarkan indeks total

\begin{tabular}{lrccc}
\hline \multirow{2}{*}{$\begin{array}{c}\text { Strategi } \\
\text { koping }\end{array}$} & Rendah & Sedang & Tinggi & Total \\
\cline { 2 - 5 } & $\%$ & $\%$ & $\%$ & $\%$ \\
\hline $\begin{array}{l}\text { Pengurangan } \\
\text { pengeluaran }\end{array}$ & 7,5 & 79,2 & 13,2 & 100,0 \\
$\begin{array}{l}\text { Penambahan } \\
\text { pendapatan }\end{array}$ & 30,2 & 66,0 & 3,8 & 100,0 \\
\hline $\begin{array}{l}\text { Keterangan: } \\
\%=\text { Persentase }\end{array}$ & & & & \\
\hline
\end{tabular}




\section{Kesejahteraan Objektif}

Kesejahteraan objektif keluarga diukur dari pendapatan per kapita keluarga. Garis kemiskinan yang digunakan adalah garis kemiskinan Kabupaten Bogor tahun 2011, yaitu sebesar Rp235 682 per kapita per bulan (BPS 2011). Berdasarkan Garis Kemiskinan BPS Kabupaten Bogor (2011), diketahui bahwa hampir tiga per empat ibu (73,60\%) terkategori tidak miskin. Sedangkan sisanya sebesar 26,40 persen terkategori miskin.

Bank Dunia mengukur kesejahteraan menggunakan garis kemiskinan Bank Dunia, yaitu penghasilan sebesar US\$1,25 per hari dan US $\$ 2$ per hari. Acuan perbandingan garis kemiskinan digunakan nilai tukar daya beli (Purchasing Power Parity), yakni sebesar Rp7 800,00 untuk batas US\$1,25 per kapita per hari dan Rp12.480,00 untuk batas US\$2 per kapita per hari. Berdasarkan garis kemiskinan US\$1,25 per kapita per hari, penelitian menunjukkan hasil yang sama dengan garis kemiskinan BPS. Berdasarkan garis kemiskinan Bank Dunia US\$2, sebanyak 49,10 persen keluarga responden terkategori miskin. Sedangkan 50,90 persen keluarga responden terkategori tidak miskin.

Pengaruh Karakteristik Keluarga, Modal Sosial, dan Strategi Koping Ekonomi terhadap Kesejahteraan Objektif

Hasil analisis regresi logistik menunjukkan model yang dibangun untuk menganalisis variabel bebas (karakteristik keluarga, modal sosial, dan strategi koping) yang berpengaruh terhadap kesejahteraan objektif memiliki koefesien Negelkerke $R$ Square sebesar 0,427. Hasil tersebut menunjukkan bahwa sebesar 42,7 persen variabel kesejahteraan objektif keluarga dapat dijelaskan oleh variabel bebas dan sisanya $(57,3 \%)$ dijelaskan oleh variabel lain. Usia ibu berpengaruh positif terhadap kesejahteraan objektif keluarga. Hal ini berarti bertambahnya usia ibu akan berpeluang lebih besar untuk sejahtera secara objektif. Hasil analisis disajikan pada Tabel 4 .

Tabel 3 Sebaran pendapatan keluarga berdasarkan garis kemiskinan BPS dan Bank Dunia

\begin{tabular}{lcrr}
\hline \multirow{2}{*}{ Pendapatan } & \multicolumn{1}{c}{ BPS } & US\$1,25 & US\$2 \\
\cline { 2 - 4 } & \multicolumn{1}{c}{$\%$} & \multicolumn{1}{c}{$\%$} & \multicolumn{1}{c}{$\%$} \\
\hline Miskin & 26,4 & 26,4 & 49,1 \\
Tidak miskin & 73,6 & 73,6 & 50,9 \\
Total & 100,0 & 100,0 & 100,0 \\
\hline Keterangan: & & & \\
\%=Persentase & & &
\end{tabular}

Variabel modal sosial yang berpengaruh terhadap kesejahteraan objektif keluarga adalah dimensi kepercayaan $(\beta=-0,086)$ dan jaringan sosial $(\beta=0,061)$. Kepercayaan berpengaruh positif terhadap kesejahteraan objektif. Hasil ini menunjukkan bahwa penurunan tingkat kepercayaan keluarga berpeluang lebih besar untuk sejahtera secara objektif. Sementara itu, jaringan sosial berpengaruh positif terhadap kesejahteraan keluarga secara objektif. Hasil ini menunjukkan bahwa peningkatan jaringan sosial keluarga berpeluang lebih besar untuk sejahtera secara objektif. Variabel strategi koping ekonomi yang memengaruhi kesejahteraan objektif keluarga adalah strategi pengurangan pengeluaran $(\beta=-$ 0,092, $\quad \alpha=0,05)$. Strategi pengurangan pengeluaran memengaruhi kesejahteraan objektif keluarga secara signifikan negatif. Penurunan jumlah strategi pengurangan pengeluaran yang dilakukan keluarga berpeluang lebih besar untuk membuat keluarga menjadi lebih sejahtera secara objektif.

Tabel 4 Koefisien regresi untuk analisis pengaruh karakteristik keluarga, modal sosial, dan strategi koping ekonomi terhadap kesejahteraan objektif

\begin{tabular}{|c|c|c|c|}
\hline \multirow[t]{2}{*}{ Variabel } & \multicolumn{2}{|c|}{$\begin{array}{c}\text { Kesejahteraan } \\
\text { objektif keluarga } \\
\text { (0=tidak sejahtera, } \\
1=\text { sejahtera })\end{array}$} & \multirow[t]{2}{*}{ Sig } \\
\hline & $\beta$ & $\operatorname{Exp}(\beta)$ & \\
\hline \multicolumn{4}{|l|}{$\begin{array}{l}\text { Karakteristik } \\
\text { Keluarga }\end{array}$} \\
\hline Usia ibu (tahun) & 0,119 & 1,126 & $0,092^{*}$ \\
\hline $\begin{array}{l}\text { Lama pendidikan ibu } \\
\text { (tahun) }\end{array}$ & 0,128 & 1,136 & 0,304 \\
\hline $\begin{array}{l}\text { Status kerja }(0=\text { tidak } \\
\text { bekerja; } 1=\text { bekerja) }\end{array}$ & $-0,032$ & 0,968 & 0,978 \\
\hline $\begin{array}{l}\text { Besar keluarga } \\
\text { (orang) }\end{array}$ & $-0,269$ & 0,764 & 0,480 \\
\hline \multicolumn{4}{|l|}{ Modal Sosial } \\
\hline Kepercayaan (skor) & $-0,086$ & 0,918 & $0,052^{*}$ \\
\hline $\begin{array}{l}\text { Jaringan sosial } \\
\text { (skor) }\end{array}$ & 0,061 & 1,063 & $0,064^{*}$ \\
\hline Norma sosial (skor) & 0,009 & 1,009 & 0,806 \\
\hline \multicolumn{4}{|l|}{$\begin{array}{l}\text { Strategi Koping } \\
\text { Ekonomi }\end{array}$} \\
\hline $\begin{array}{l}\text { Pengurangan } \\
\text { pengeluaran (skor) }\end{array}$ & $-0,092$ & 0,912 & $0,040^{\star *}$ \\
\hline $\begin{array}{l}\text { Penambahan } \\
\text { pendapatan (skor) }\end{array}$ & $-0,010$ & 0,990 & 0,815 \\
\hline Chi square & & & 10,022 \\
\hline Negelkerke $R^{2}$ & & & 0,427 \\
\hline $\begin{array}{l}\text { Keterangan: } \\
{ }^{*} \text { Signifikan pada } p<0,10, \\
\star \star * \text { Signifikan pada } p<0,05 \\
{ }^{* *} \text { Signfikan pada } p<0,01\end{array}$ & & & \\
\hline
\end{tabular}




\section{PEMBAHASAN}

Kesejahteraan keluarga erat kaitanya dengan karakteristik keluarga. Hasil penelitian menunjukkan bahwa lama pendidikan yang ditempuh ibu dari keluarga dengan perempuan sebagai kepala keluarga masih tergolong rendah yaitu 7,8 tahun. Sejalan dengan hasil penelitian Joshi (2004) bahwa rata-rata ibu dari keluarga dengan perempuan sebagai kepala keluarga menamatkan pendidikannya pada tingkat sekolah dasar. Terdapat hubungan positif signifikan antara lama pendidikan dengan kesejahteraan objektif keluarga. Artinya semakin tinggi pendidikan yang ditempuh ibu dari keluarga perempuan sebagai kepala keluarga maka semakin meningkatkan kesejahteraan objektif keluarga. Penelitian Leibowitz (1988) menunjukkan bahwa pendapatan yang diperoleh seseorang sangat erat kaitannya dengan pendidikan dan pengalaman yang telah ditempuh. Berdasarkan karakteristik pekerjaan, ibu yang tidak menamatkan wajib belajar sembilan tahun memiliki pekerjaan sebagai buruh, wiraswasta, bahkan tidak memiliki pekerjaan. Secara keseluruhan, jenis pekerjaan ibu didominasi sebagai wiraswasta. Hal ini sejalan dengan penelitian Chamwali (2000) dan Eboiyehi (2013) yang menunjukkan bahwa perempuan sebagai kepala keluarga melakukan bisnis kecil atau berdagang sebagai strategi nafkah untuk bertahan hidup.

Penelitian ini mengkaji lebih khusus pada modal sosial yang dimiliki keluarga. Modal sosial didefinisikan sebagai kepercayaan, jaringan, dan norma yang melandasi adanya kerjasama untuk mencapai keuntungan (Siisiainen, 2000). Hasil penelitian menunjukkan bahwa rata-rata keluarga memiliki tingkat kepercayaan yang tinggi pada hampir setiap aspek. Kepercayaan dijadikan sumber untuk membuat pekerjaan rumah dan pekerjaan bersama masyarakat lebih cepat terselesaikan. Kepercayaan merupakan kunci modal sosial yang dapat menjadi dasar seseorang dapat bekerjasama dengan baik dan kepercayaan membentuk ketersediaan diantara anggota masyarakat untuk menempatkan kepentingan bersama di atas kepentingan pribadi (Fukuyama, 2002).

Pada penelitian ini, kepercayaan dijadikan landasan bagi keluarga dalam menjalin hubungan dengan semua anggota keluarga, tetangga, dan masyarakat. Kepercayaan menjadi sarana menciptakan kedamaian, menjamin keutuhan, dan meredam kekacauan yang muncul di keluarga dan masyarakat.
Fukuyama (2002) menambahkan bahwa kepercayaan menjadi energi yang dapat membuat kelompok masyarakat atau organisasi dapat bertahan. Kekerabatan dan agama yang cenderung homogen pada lingkungan masyarakat pada penelitian ini mendukung adanya modal sosial bagi keluarga. Hampir seluruh keluarga mengikuti kelompok keagamaan (pengajian) dengan anggota yang didominasi berasal dari agama dan suku yang sama di lingkungan tempat tinggal. Semakin homogen anggota di dalam kelompok, semakin mudah kepercayaan dibentuk antaranggota kelompok (Grootaert, 1999).

Modal sosial adalah sumber daya keluarga yang digunakan untuk mengembangkan akses melalui jaringan sosial (Haddad \& Maluccio, 2002). Pada penelitian ini, sebagian besar keluarga pada penelitian ini memiliki tingkat jaringan sosial yang tinggi meliputi banyaknya keluarga yang dikenal dalam lingkungan tempat tinggal, teman/relasi suami/istri yang dikenal, dan teman anak. Hossain (2006) memaparkan dalam hasil penelitiannya bahwa masyarakat miskin memelihara hubungan pertetanggaan untuk bertahan hidup. Grootaert, Gi-Tai, dan Swamy (1999) menjelaskan bahwa modal sosial berupa jaringan sosial yang dibangun dengan memerhatikan latar belakang sosial, agama, atau budaya. Pada penelitian ini, sebagian besar keluarga memiliki teman/relasi yang relatif homogen dari segi agama dan budaya. Keluarga merupakan masyarakat yang tinggal di lingkungan yang didominasi oleh agama Islam dan budaya Sunda. Heterogenitas kelompok sosial yang dimiliki keluarga pada umumnya dilandasi oleh latar belakang sosial dan ekonomi. Grootaert, Gi-Tai, dan Swamy (1999) memaparkan bahwa semakin heterogen dimensi pendidikan dan status ekonomi anggota kelompok makan akan memberikan keuntungan yang lebih besar. Hasil penelitian ini menunjukkan bahwa keikutsertaan keluarga dalam organisasi atau kelompok sosial masih rendah. Selain itu, keluarga sulit menemukan masyarakat yang siap membantu ketika keluarga mendadak membutuhkan uang untuk keperluan keluarga. Menurut Grootaert (1999), iuran kelompok merupakan salah satu aspek penting dalam pembentukan modal sosial. Hal ini akan memengaruhi peningkatan aset dan akses yang lebih baik untuk memperoleh kredit serta meningkatkan tabungan keluarga. Kelompok sosial yang diikuti keluarga merupakan kelompok keagamaan (pengajian) yang tidak memberikan keuntungan ekonomi secara signifikan. Jenis kelompok sosial dan lamanya keterlibatan akan memengaruhi fungsi 
modal sosial yang berkaitan memberikan keuntungan pada keluarga (Coleman, 2012).

Grootraet (1999) memaparkan dimensi lain yang penting dalam pembentukan jaringan sosial yaitu indeks kepadatan dan keaktifan anggota, indeks pembuatan keputusan, dan indeks kehadiran. Hasil penelitian ini menunjukkan bahwa keaktifan, kehadiran, dan kedudukan keluarga dalam kelompok sosial yang diikuti masih rendah. Selain itu, masih banyak keluarga yang tidak mengikuti kelompok sosial. Temuan ini sejalan dengan penelitian Grootaert (1999) yang menyimpulkan bahwa perempuan kepala rumah tangga memiliki jumlah dan partisipasi dalam pengambilan keputusan kelompok lebih rendah dibandingkan dengan kepala rumah tangga laki-laki. Partisipasi dalam pengambilan keputusan kelompok dipengaruhi oleh jenis kelamin, usia, tingkat pendidikan dan pendapatan (Haddad \& Maluccio, 2002; Grootaert, 1999). Sedangkan, hasil penelitian menunjukkan karakteristik pendidikan dan pendapatan ibu masih tergolong rendah.

Norma sosial menggambarkan nilai-nilai yang disepakati oleh masyarakat sebagai acuan dalam berperilaku. Norma sosial merupakan kontrol modal sosial yang menjangkau diterapkannya kerjasama, seperti kejujuran, solidaritas, pemenuhan kewajiban dan rasa keadilan (Suharto, 2007). Penelitian ini mengukur frekuensi diterapkannya norma sosial yang ditanamkan dalam keluarga untuk dapat hidup teratur dalam keluarga dan masyarakat. Hasil penelitian menunjukkan ratarata indeks total skor yang tinggi pada norma sosial. Suharto (2007) menjelaskan bahwa norma sosial mengidentifikasikan konsistensi modal sosial pada individu atau keluarga. Terdapat dua sifat kekonsistenan modal sosial, yaitu modal sosial bersifat ekslusif (hanya berlaku untuk keluarga atau kelompoknya saja) atau bersifat inklusif (berlaku bagi kelompok lain yang lebih luas). Hasil penelitian menunjukkan rata-rata keluarga menerapkan norma sosial secara inklusif, yakni dijalankan oleh seluruh anggota keluarga tanpa terkecuali, dimana pun, dan kapan pun.

Hasil penelitian menunjukkan bahwa terdapat hubungan negatif dan signifikan antara pendapatan per kapita keluarga dengan strategi koping ekonomi $(r=0,370, p=0,006)$. Artinya, semakin bertambah pendapatan per kapita keluarga maka akan menurunkan strategi koping yang dilakukan oleh keluarga. Semakin sejahtera keluarga maka akan semakin sedikit melakukan strategi koping (Rosidah, Hartoyo, \&
Muflikhati, 2012). Hasil penelitian menunjukkan bahwa rata-rata indeks strategi koping pengurangan pengeluaran lebih tinggi dilakukan keluarga dibandingkan strategi penambahan pendapatan. Keluarga lebih sering melakukan strategi pengurangan pengeluaran daripada penambahan pendapatan ketika pendapatan sedang menurun (Johan, Muflikhati, \& Mukhti, 2013). Strategi koping pengurangan pengeluaran lebih mudah dilakukan keluarga dibandingkan strategi penambahan pendapatan. Strategi peningkatan penambahan membutuhkan sumber daya manusia dan jejaring sosial untuk meningkatkan sumber daya uang (Rosidah, Hartoyo, \& Muflikhati, 2012). Berdasarkan kajian modal manusia, lebih dari dua pertiga keluarga tidak memiliki keterampilan khusus yang dapat menghasilkan barang untuk meningkatkan pendapatan. Hasil penelitian menunjukkan bahwa strategi koping yang selalu dilakukan keluarga diantaranya adalah dengan membeli pangan yang lebih murah, mengubah distribusi pangan, mengganti obat yang mahal dengan yang murah, memilih tempat berobat yang lebih murah, menangguhkan pengobatan, mengurangi pembelian pakaian, dan mengurangi pembelian perabot rumah tangga.

Kesejahteraan objektif didefinisikan sebagai tingkat pemenuhan kebutuhan dasar dan perkembangan secara objektif yang mengacu pada standar normatif dan ideal (Sunarti, 2013). Penelitian ini mengukur kesejahteraan menggunakan dua indikator, yaitu pendapatan per kapita berdasarkan garis kemiskinan Badan Pusat Statistik (BPS) dan Bank Dunia. Hasil penelitian menunjukkan bahwa sebagian besar keluarga tergolong tidak miskin berdasarkan garis kemiskinan BPS. Sedangkan berdasarkan garis kemiskinan Bank Dunia US\$2, penelitian menunjukkan hampir separuh keluarga termasuk dalam kategori miskin. Berdasarkan perbandingan rata-rata pendapatan dengan pengeluaran keluarga, dapat diketahui bahwa rata-rata pengeluaran keluarga lebih besar dibandingkan dengan ratarata pendapatan per bulan. Garis kemiskinan ditentukan berdasarkan kebutuhan dasar minimum yang dipengaruhi oleh faktor seperti adat dan kebiasaan, tingkat pembangunan, iklim, dan berbagai faktor ekonomi lainnya (Syarief \& Hartoyo, 1998). Perbedaan persentase kesejahteraan objektif dapat disebabkan garis kemiskinan yang digunakan BPS diperuntukan bagi Negara Indonesia, khususnya Kabupaten Bogor dalam penelitian ini. Sedangkan garis kemiskinan Bank Dunia digunakan untuk mengukur kemiskinan pada 
standar internasional. Hal ini akan menimbulkan perbedaan diantara indikator yang mengukur kemiskinan pada skala kecil seperti lingkup daerah, dengan skala yang lebih luas seperti lingkup dunia. Pernyataan serupa dipaparkan oleh Syarief dan Hartoyo (1998) bahwa garis kemiskinan akan bervariasi antarkelompok masyarakat dan wilayah.

Terdapat selisih persentase yang cukup berarti dalam mengidentifikasikan kemiskinan yang dialami keluarga dengan perempuan sebagai kepala keluarga dengan kemiskinan secara nasional. Terdapat 28,59 juta orang $(11,66 \%)$ penduduk Indonesia yang terkategori miskin (BPS, 2013). Pengukuran kemiskinan secara nasional dilakukan bagi keluarga secara umum. Hasil penelitian ini menunjukkan persentase kemiskinan yang lebih besar pada keluarga dengan perempuan sebagai kepala keluarga (26,40\%). Artinya, keluarga dengan dengan perempuan sebagai kepala keluarga berpeluang lebih besar untuk menjadi miskin dibandingkan dengan keluarga secara umum. Hal ini sejalan dengan penelitian yang dilakukan oleh Joshi (2004) yang menunjukkan bahwa perempuan sebagai kepala keluarga memiliki kehidupan yang lebih memprihatinkan dibandingkan dengan perempuan yang menikah.

Berdasarkan hasil uji regresi menunjukkan bahwa variabel karakteristik keluarga yang berpengaruh terhadap kesejahteraan objektif keluarga dengan perempuan sebagai kepala keluarga adalah usia ibu. Peningkatan usia ibu berpeluang lebih besar untuk sejahtera secara objektif. Lamanya rentang hidup seseorang akan berpeluang menambah pengalaman dan kemampuan yang dapat dikembangkan sebagai strategi nafkah untuk meningkatkan pendapatan. Lama pendidikan ibu, status kerja, dan besar keluarga ditemukan tidak memiliki peluang yang signifikan untuk memengaruhi kesejahteraan objektif keluarga. Penelitian Elmanora, Muflikhati, dan Alfiasari (2012) juga menunjukkan tidak ditemukan pengaruh secara signifikan antara lama pendidikan ibu yang ditempuh terhadap kesejahteraan objektif keluarga.

\footnotetext{
Faktor strategi koping ekonomi pengurangan pengeluaran berpengaruh signifikan negatif terhadap kesejahteraan objektif keluarga. Hal ini berarti bahwa penurunan jumlah strategi koping pengurangan pengeluaran keluarga dengan perempuan sebagai kepala keluarga berpeluang lebih besar untuk sejahtera secara objektif. Terdapat hubungan negatif signifikan antara pendapatan
}

per kapita sebagai alat ukur kesejahteraan objektif dengan strategi koping pengurangan pengeluaran. Hal ini menunjukkan kondisi kritis keluarga dalam bidang ekonomi yang berpeluang menurunkan kesejahteraan. Ketika mengalami penurunan pendapatan, keluarga cenderung melakukan strategi koping pengurangan pengeluaran yang lebih tinggi (Johan, Muflikhati, \& Mukhti, 2013).

Variabel modal sosial yang berpengaruh terhadap kesejahteraan objektif keluarga adalah dimensi kepercayaan dan jaringan sosial. Hasil penelitian menunjukkan bahwa keluarga dengan kepercayaan yang rendah dapat memiliki kesejahteraan objektif yang lebih tinggi. Hal ini didukung oleh homogennya kerabat dan kelompok sosial dalam segi agama, suku, serta latar belakang pendidikan dan ekonomi, yang dimiliki keluarga. Kepercayaan ditemukan berpengaruh negatif terhadap kesejahteraan objektif. Hal ini dapat diakibatkan adanya kecenderungan homogen pada latar belakang pendidikan dan ekonomi kerabat atau anggota kelompok sosial keluarga. Grootaert, Gi-Tai, Swamy (1999) memaparkan bahwa semakin heterogen dimensi pendidikan dan status ekonomi anggota kelompok atau kekerabatan, akan memberikan keuntungan yang lebih besar. Peningkatan jaringan sosial yang dimiliki keluarga berpeluang lebih besar untuk membuat keluarga menjadi lebih sejahtera secara objektif. Temuan ini sejalan dengan hasil penelitian yang dilakukan oleh Alfiasari (2008) yang menunjukkan bahwa semakin tinggi modal sosial, semakin tinggi peningkatan kesejahteraan ekonomi keluarga. Kajian Fukuyama (2009) juga menyimpulkan bahwa modal sosial memiliki kekuatan untuk memengaruhi kemajuan ekonomi dan kesejahteraan sosial. Penelitian ini juga menemukan semakin banyaknya organisasi atau kelompok sosial yang diikuti perempuan sebagai kepala keluarga maka akan semakin meningkatkan jaringan sosial.

\section{SIMPULAN DAN SARAN}

Kajian pada keluarga dengan perempuan sebagai kepala keluarga dalam penelitian ini menunjukkan bahwa modal sosial yang dimiliki keluarga baik pada dimensi kepercayaan, jaringan sosial, dan norma sosial memperlihatkan dominasi persentase kategori tinggi. Namun, pemanfaatan dan jenis jaringan sosial yang diikuti oleh keluarga dinilai belum optimal. Jumlah kelompok sosial yang diikuti oleh perempuan sebagai kepala keluarga masih tergolong rendah. Jenis kelompok sosial yang diikuti belum mendukung adanya 
pengembangan sumber daya keluarga. Strategi koping pengurangan pengeluaran lebih banyak digunakan keluarga dibandingkan dengan penambahan pendapatan. Hasil penelitian menunjukkan terdapat peluang usia ibu yang berpengaruh terhadap kesejahteraan objektif keluarga secara signifikan positif. Hasil penelitian juga menduga bahwa dimensi kepercayaan dan jaringan sosial pada modal sosial berpengaruh terhadap kesejahteraan objektif keluarga. Penurunan strategi koping pengurangan pengeluaran yang dilakukan keluarga dengan perempuan sebagai kepala keluarga memiliki peluang lebih besar untuk sejahtera secara objektif.

Rekomendasi berkaitan dengan modal sosial lebih ditekankan pada optimalisasi pemanfaatan modal dan pengembangan sumber daya. Perlu adanya pembentukan kebijakan atau program yang dapat membangun modal sosial keluarga dengan perempuan sebagai kepala keluarga melalui pembentukan kelompok sosial berbasis ekonomi. Pelatihan kewirausahaan dapat dicanangkan untuk mengembangkan keterampilan perempuan sebagai kepala keluarga.

\section{DAFTAR PUSTAKA}

Alfiasari. (2008). Analisis modal sosial dalam pemberdayaan ekonomi keluarga miskin di Kelurahan Kedung Jaya, Kecamatan Tanah Sareal, Kota Bogor. Jur. ilm. Kel. \& Kons., 1(1), 29-42.

[BPS] Badan Pusat Statistik. (2011). Jumlah dan persentase penduduk miskin dan garis kemiskinan menurut kabupaten/kota tahun 2011. Diambil dari jabar.bps.go.id/subyek. [diunduh 30 April 2013].

[BPS] Badan Pusat Statistik. (2013). Konsep kemiskinan. Diambil dari http://www.bps.go.id. [diunduh 2013 April 30].

Chamwali. (2000). Survival and accumulations strategies at the rural-urban interface: A study of Ifakara Town, Tanzania. Research Report, No.003. Institute of Development Management, Mzumbe.

Coleman, J. S. (2012). Social capital in creation of human capital. American Journal of Sociology, 94.

Eboiyehi, F. A. (2013). Our lives are in your hands: survival strategies of elderly woman heads households in rural Nigeria. International Journal of Humanities and Social Science, 3(5).
Elmanora, Muflikhati, I., \& Alfiasari. (2012). Kesejahteraan keluarga petani kayu manis. Jur. ilm. Kel. \& Kons., 5(1), 58-66.

[Forum Pekka] Forum Pemberdayaan Perempuan Kepala Keluarga. Perempuan kepala keluarga. Diambil dari www.pekka.or.id. [diunduh 23 April 2014].

Fukuyama. (2002). Social capital and civil society. IMF Working Paper, WP/00/74. International Monetary Fund.

Farrington, Ramasut, \& Walker. (2002). Sustainable livelihoods approaches in urban area: General lessons with illustrations from Indian cases. Working paper 162, London.

Grootaert, C., Gi-Tai Oh, S. \& Wamy, A. (1999). Social capital and development outcomes burkina faso. Working Paper, No.7, The World Bank. Social Development Department, Washington DC, US.

Grootaert, C. (1999). Social capital, household walfare and poverty in Indonesia. Working Paper, 6The World Bank. Social Development Department, Washington DC, US.

Haddad, L., \& Maluccio, J. (2002). Social capital and household walfare in South Africa: pathways of influence. Paper for presentation at the Centre for the study of African Economies. Washington DC, US.

Hastuti, D., Alfiasari, \& Sarwaprasodjo, S. (2009). Analisis transisi nilai budaya, nilai keluarga, dan nilai anak pada keluarga petani dan pengaruhnya terhadap kualitas kehidupan sebagai bentuk penguatan modal sosial masyarakat pertanian. Laporan Penelitian Hibah Bersaing. Bogor, ID: Institut Pertanian Bogor.

Hastuti, D., \& Milyawati, L. (2009). Dukungan keluarga, pengetahuan, dan persepsi ibu serta hubungannya dengan strategi koping ibu pada anak dengan gangguan autism spectrum disorder (ASD). Jur. ilm. Kel. \& Kons., 2(2), 137-142.

Horrell, S., \& Krishnan, P. (2006). Poverty and productivity in female-headed households in Zimbabwe. Journal of Development Studies.

Hossain, S. (2006). Poverty, household strategies, and coping with urban life: examining livelihood framework in Dhaka City, Bangladesh. Bangladesh e-Journal of Sociology, 2(1). 
Johan, I. R., Muflikhati, I., \& Mukhti, D. S. (2013). Gaya hidup, manajemen keuangan, strategi koping, dan kesejahteraan keluarga nelayan. Jur. ilm. Kel. \& Kons., 6(1), 30-38.

Joshi, S. (2004). Female household-headship in rural bangladesh: Incidence, determinants and impact on children's schooling. Center Discussion Paper, 894, Economic Growth Center Discussion Paper Series, Yale University, US.

Leibowitz, A. (1998). Home investments in children. Journal of Political Economy.

Puspitawati, H. (2012). Gender dan keluarga. Bogor, ID: IPB Press.

Rosidah, U., Hartoyo, \& Miflikhati, I. (2012). Kajian strategi koping dan perilaku investasi anak pada keluarga buruh pemetik melati gambir. Jur. ilm. Kel. \& Kons., 5(1).

Siisiainen, M. (2000). Two concepts of social capital: Bourdieu vs. Putnam. ISTR Fourth International Conference, Trinity Collage, Dublin.
Suharto, E. (2007). Islam, modal sosial dan pengentasan kemiskinan. "Indonesia Social Economic Outlook", Dompet Dhuafa, Jakarta.

Sunarti, E., \& Fitriani. (2010). Kajian modal sosial, dukungan sosial, dan ketahanan keluarga nelayan di daerah rawan bencana. Jur. ilm. Kel. \& Kons., 3(2), 93100.

Syarief, H., \& Hartoyo. (1998). Beberapa aspek dalam kesejahteraan keluarga. Prosiding. Disampaikan pada seminar Keluarga Menyongsong Abad XXI dan Peranannya dalam Pengembangan Sumber daya Manusia Indonesia, Kampus IPB Dramaga, Bogor.

Wagle, U. (2008). Multidimensional Poverty Measurement: Concept and Applications. USA: Springer.

[World Bank]. (2013). Indonesia berhasil meningkatkan Indikator Pembangunan Manusia tetapi separuh dari penduduk indonesia masih tetap rentan terhadap kemiskinan. Diambil dari http://web.worldbank.org/. [diunduh 2 Jun 2014]. 